\title{
METODE BIMBINGAN DAN KONSELING ISLAM DALAM MENANAMKAN KEDISIPLINAN SHOLAT DHUHA PADA ANAK HIPERAKTIF DI MI NURUL ISLAM NGALIYAN SEMARANG
}

\author{
Hidayatul Khasanah, Yuli Nurkhasanah, Agus Riyadi \\ UIN Walisongo Semarang \\ Email: Hidayah21khasan@gmail.com, yuli.nurkhasanah@walisongo.ac.id; \\ agus.riyadi@walisongo.ac.id
}

\begin{abstract}
Abstrak
This research aimed to describe the characteristics of hyperactive children and analyze methods of Islamic guidance and counseling in instilling discipline of Duha prayer in hyperactive children in MI Nurul Islam Ngaliyan Semarang. This research is qualitative research. The data source is a teacher as well as a hyperactive child. Methods of data collection using interviews, observation, and documentation. The results showed that hyperactive children have discipline problems in implementing the Duha prayer in congregation. Islamic guidance and counseling methods used to embed discipline of Duha prayer for hyperactive children consisting of four methods: the method of habituation, role model, motivation and supervision.

Penelitian ini merupakan penelitian kualitatif yang bertujuan untuk mendiskripsikan karakteristik anak hiperaktif dan menganalisis metode bimbingan dan konseling Islam dalam menanamkan kedisiplinan shalat dhuha pada anak hiperaktif di MI Nurul Islam Ngaliyan Semarang. Jenis penelitian ini merupakan penelitian kualitatif. Sumber data penelitian ini adalah guru serta anak hiperaktif. Metode pengumpulan data menggunakan wawancara, observasi, dan dokumentasi. Hasil penelitian menunjukkan bahwa pertama anak hiperaktif memiliki problem kedisiplinan dalam melaksanakan shalat dhuha berjamaah. Kedua, metode bimbingan dan konseling Islam yang digunakan untuk menanamkan kedisiplian shalat dhuha bagi anak hiperaktif terdiri dari empat metode yaitu metode pembiasaan, metode tauladan, metode nasehat (motivasi), dan metode pengawasan ketika shalat dhuha berjamaah berlangsung.
\end{abstract}

Keywords: Method of Islamic guidance and counseling, discipline, Dhuha prayer and Hyperactive children. 


\section{A. Pendahuluan}

Al-Qur'an dalam konteks pendidikan menjelaskan pengertian anak dalam dua tipologi yaitu: Al-Aulad dan al-Banun. Tafsir Al-Misbah karya Muhammad Quraish Shihab menyatakan bahwa istilah aulad biasanya dikaitkan dengan konotasi makna anak secara pesimis yaitu anak dan harta adalah sebagai cobaan, sehingga anak memerlukan perhatian yang khusus. Sedangkan istilah al-Banun mengandung pemahaman anak secara optimis yaitu anak sebagai perhiasan kehidupan dunia, sehingga menimbulkan kebanggaan dan ketentraman khusus dalam hati. Orang tua sebagai pemegang amanah haruslah memproteksi anak agar pemaknaan anak tidak berkonotasi negatif, maka sebagai orang tua harus bijak menjaga amanah putra-putrinya supaya tetap di koridornya Allah SWT.1

Anak adalah anugerah terbaik bagi orang tua dan merupakan amanah yang akan dimintai pertanggungjawabannya oleh Allah SWT. Sebagaimana kita ketahui bahwa Allah SWT menerangkan di dalam AlQur'an tentang petuah sang bijak Luqman yang merupakan bentuk pendidikan kepada anak-anaknya. ${ }^{2}$ Upaya mencapai kualitas ibadah yang sempurna pada masa dewasa maka sebaiknya pembinaan ibadah dilakukan sejak dini atau sejak kanak-kanak. Karena pembinaan ibadah sendiri merupakan penyempurna dari pembinaan aqidah. Menurut Syekh Jamaludin Mahfudz menyatakan bahwa sejak dini seorang anak sudah dilatih ibadah, diperintah melakukannya dan diajarkan hal-hal yang haram serta yang halal. Islam menekankan kepada kaum muslim untuk memerintahkan anak-anak mereka menjalankan ibadah shalat ketika mereka berusia tujuh tahun. ${ }^{3}$

Anak pada usia tujuh sampai sembilan tahun, akan mengalami masa imitasi (masa mencontoh) apa yang mereka lihat. Pada usia tujuh sampai sembilan tahun masa terbaik untuk menanamkan perilaku yang baik dan kedisiplinan beribadah. Islam menekankan kepada kaum muslim untuk memerintahkan anak-anak mereka menjalankan shalat ketika mereka berusia tujuh tahun, seperti yang dianjurkan oleh Nabi Muhammad SAW yaitu melatih anak untuk taat beribadah. Sabda Rosulullah SAW:

1Muhammad Quraish Shihab, Tafsir Al-Misbah: Pesan, Kesan, dan Keserasian Al-Quran , Jakarta: Lentera Hati,2008,hlm.425

2 Abu Hamida, Indahnya dan Nikmatnya Shalat: Jadikan Shalat Anda Bukan Sekedar Ruku dan Sujud, Bandung: Pustaka Hidayah, 2009, hlm.135

3, Syekh Jamaludin, Psikologi Perkembangan Anak dan Remaja Muslim, Jakarta: Pustaka Al-Kautsar, 2003, hlm.128 


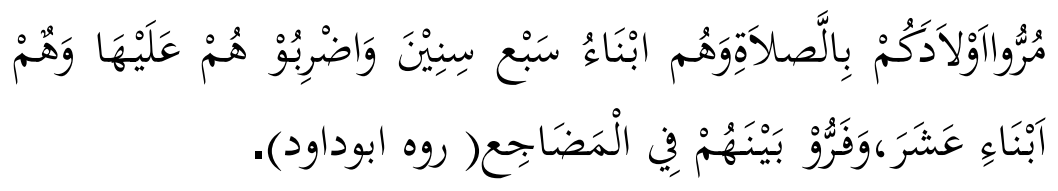

"Suruhlah anak-anakmu mengerjakan shalat, sedang mereka berusia tujuh tahun. Dan pukullah mereka karena meninggalkannya, sedang mereka berusia sepuluh tahun. Dan pisahlah di antara mereka itu dari tempat tidurnya" (HR. Abu Daud).

Hadits tersebut menjelaskan bahwa kewajiban mendidik anak untuk melakukan sholat itu harus dilakukan sejak dini atau ketika berusia tujuh tahun, jangan sampai anak sudah berusia sepuluh tahun tidak mau melaksanakan shalat atau bahkan belum bisa melakukan sholat . ${ }^{4}$ Anak usia sepuluh sampai tiga belas tahun pada umumnya telah menguasai gerakangerakan sholat dan bacaannya. Hal ini dikarenakan sejak dini mereka sudah dikenalkan dengan ibadah sholat melalui keteladanan langsung dari orang tua, bimbingan dari guru atau melalui berbagai media. ${ }^{5}$ Tidak terlupakan pula peran TPQ yang membantu memberi pelajaran praktikpraktik sholat ataupun bacaan-bacaan dalam sholat. Perlu diingat pula pada masa ini disebut masa persiapan, latihan dan pembiasaan untuk menyambut masa pembebanan kewajiban (taklif) ketika ia baligh nanti. ${ }^{6}$

Selain itu, ditinjau dari perkembangan mental intelektual anak, mereka sudah dapat mereaksikan rangsangan intelektual atau melaksanakan tugas-tugas belajar yang menurut kemampuan intelektual atau kemampuan kognitif (membaca, menulis, atau menghafal). Dan ditinjau dari perkembangan psikomotoriknya, gerakan motorik mereka sudah dapat terkoordinasi dengan baik. Tentu saja perkembangan ini berbeda pada anak yang mengalami gangguan pemusatan perhatian disertai hiperaktif.7

${ }^{4}$ Abdullah, Muhammad ibnu Ahmad Al-Ansori, Tafsir Al-Qurtubi, Jakarta: Manshuurah, 2001, hlm.527

5Syekh Jamaludin Mahfudz,, Psikologi Perkembangan Anak dan Remaja Muslim, Jakarta: Pustaka Al-Kautsar, 2003, hlm.126

6Mansur, Pendidikan Anak Usia Dini dalam Islam, Yogyakarta: Pustaka Belajar, 2014, hlm.134

${ }^{7}$ Rohmah, Elfi Yuliana, Psikologi Perkembangan, Ponorogo: STAIN Ponorogo Press, 2005,hlm.166 
Anak hiperaktif menunjukkan adanya suatu pola perilaku pada seorang yang menunjukkan sikap tidak bisa diam, tidak terkendali, tidak menaruh perhatian dan impulsif (bertindak sekehendak hatinya). Anak hiperaktif selalu bergerak dan tidak pernah merasakan asyiknya permainan, dikarenakan perhatian mereka suka beralih dari satu fokus ke fokus yang lain. Mereka seakan-akan tanpa henti mencari sesuatu yang menarik dan mengasyikkan namun tidak kunjung datang. Hiperaktif juga mengacu kepada ketiadaannya pengendalian diri, contohnya dalam mengambil keputusan atau kesimpulan tanpa memikirkan akibat-akibat terkena hukuman atau mengalami kecelakaan (Mulyadi, 2009: 87).

Wiguna (2007: 5) mengemukakan karakteristik anak yang cenderung mengalami gangguan hiperaktif yaitu tidak bisa duduk diam di dalam kelas, tangan bergerak dengan gelisah, mengalami kesulitan dalam bermain atau dalam kegiatan menyenangkan bersama yang memerlukan ketenangan, impulsivitas, mengalami kesulitan dalam menunggu giliran, menjawab sebelum pertanyaan selesai atau sering menginterupsi orang lain. Anak yang hiperaktif menunjukkan semua atau hampir semua ciri-ciri di atas. Dari karakteristik dan kemampuan anak hiperaktif mengalami kesulitan dalam menguasai ibadah sholat. Karena ibadah shalat menuntut konsentrasi tinggi dan sikap tenang.

Mengenai hal ini semua guru pembimbing anak hiperaktif, untuk membimbing ibadah shalat dhuha. Bimbingan ini dilaksanakan di sekolah karena proses pendidikan dan pengajaran agama dapat dikatakan sebagai "Bimbingan". Bimbingan merupakan kegiatan dakwah Islamiah. Untuk menyeru dan mengajak manusia untuk berbuat kebaikan dan menjauhi kemungkaran. Pada esensinya dakwah terletak pada usaha pencegahan dari penyakit masyarakat yang bersifat psikis yang dilakukan dengan cara mengajak, memotivasi, serta membimbing individu agar sehat jasmani dan rohaninya. Karena dakwah yang terarah ialah memberikan bimbingan kepada umat Islam untuk betul-betul mencapai dan melaksanakan keseimbangan hidup fil dunya wal akhirah. ${ }^{8}$

Ajaran agama yang diberikan oleh guru di kelas maupun saat pelaksanaan ibadah shalat dhuha, merupakan salah satu bimbingan keagamaan kepada anak. Guru dapat memberikan contoh (tauladan) kepada anak didiknya dan sekaligus dapat mengamati secara rutin perkembangan kepribadian anak, kemajuan belajar anak, dan langsung berhadapan dengan permasalahan anak. Wali kelas merupakan guru pembina di kelas untuk mengajar juga diberi tugas khusus untuk mengelola

8Samsul MunirAmin, Bimbingan dan Konseling Islam, Jakarta: AMZAH, 2010, hlm. 24 
satu kelas siswa dan bertanggung jawab membantu kegiatan bimbingan konseling di kelasnya. Sedangkan guru pembimbing atau guru bimbingan konseling sebagai pelaksana utama mengkoordinasi semua kegiatan yang terkait dalam pelaksanaan bimbingan konseling di sekolah. Jadi wali kelas dan guru bimbingan dan konseling mempunyai tugas yang sama yaitu memberikan bimbingan kepada anak didiknya. ${ }^{9}$

Undang-Undang Sisdiknas pasal 1 Ayat 8 menyebutkan bahwa "Tenaga pendidik adalah anggota masyarakat yang bertugas membimbing, mengajar, atau melatih anak didik". Kondisi riil yang melakukan tugas ini adalah guru kelas. Selain mengajar guru juga memberikan bimbingan konseling maupun bimbingan keagamaan. Namun, tugas dalam memberikan bimbingan kepada anak didik di sekolah sudah barang tentu membutuhkan keahlian khusus maka idealnya tugas ini dilakukan oleh petugas khusus yang memahami ilmu bimbingan konseling yaitu guru bimbingan konseling. ${ }^{10}$

Guru bimbingan konseling mempunyai tanggungjawab yang sangat besar terhadap anak didik. Menurut Tohirin Bimbingan dan konseling yaitu memperoleh pemahaman yang baik terhadap diri siswa, mengarahkan diri sesuai potensi yang dimilikinya sehingga siswa mampu memecahkan masalah yang dihadapiny ${ }^{11}$ Memecahkan masalah yang dihadapi anak didik memang tugas semua guru, seperti masalah yang dialami anak hiperaktif, anak yang tidak bisa diam, selalu bergerak dan tidak bisa disiplin.

Menurut Hurlock disiplin yakni orang yang belajar secara suka rela mengikuti seorang pemimpin. Orang tua dan guru merupakan pemimpin dan anak sebagai murid yang belajar dari mereka. Pokok pertama disiplin adalah peraturan. Peraturan sebagai pola yang ditetapkan untuk tingkah laku. Pola tersebut bisa ditetapkan oleh orang tua atau guru dengan tujuan membekali anak dengan pedoman perilaku yang disetujui dalam situasi tertentu. ${ }^{12}$

Dalam hal peraturan sekolah misalnya, tidak boleh ramai dalam kelas, tidak boleh gojek sendiri ketika diajar bapak ibu guru, tidak tertib dalam melaksanakan ibadah sholat dhuha. Hal tersebut telah ditarapkan di MI Nurul Islam Ngaliyan Semarang, guna menertibkan saat melaksanakan ibadah shalat dhuha berjamaah. Penelitian ini selanjutnya berupaya

${ }^{9}$ Hamdani, Bimbingan dan Penyuluhan, Bandung: Pustaka Setia, 2012, hlm. 43

${ }^{10}$ Akhad MuhaiminAzzeet, Bimbingan Konseling di Sekolah, Yogyakarta: Ar-Ruzz, 2011, hlm. 39

${ }^{11}$ Hamdani, Bimbingan dan Penyuluhan, Bandung: Pustaka Setia, 2012, hlm. 98

${ }^{12}$ Hurlock, Perkembangan Anak Jilid I, Jakarta: Erlangga, 1989, hlm. 82 
menjelaskan karakteristik anak hiperaktif dan metode bimbingan dan konseling Islam dalam menanamkan kedisiplinan shalat dhuha pada anak hiperaktif di MI Nurul Islam Ngaliyan Semarang.

\section{B. Teori Metode Bimbingan dan Konseling Islam, Kedisiplinan Shalat Dhuha, dan Anak Hiperaktif}

\section{Bimbingan dan Konseling Islam}

\section{a) Pengertian dan Landasan Bimbingan dan Konseling Islam}

Bimbingan dan konseling Islam merupakan proses pemberian bantuan terarah, kontinu, dan sistematis kepada setiap individu agar ia dapat mengembangkan potensi atau fitrah beragama yang dimiliki secara optimal dengan cara menginternalisasikan nilai-nilai yang terkandung di dalam Al-Qur'an dan hadis Rasulullah SAW ke dalam dirinya, sehingga ia dapat hidup selaras dan sesuai dengan tuntunan Al-Quran dan Hadis. ${ }^{13}$

Arifin mengatakan bahwa bimbingan dan konseling Islam merupakan segala kegiatan yang dilakukan seseorang dalam rangka memberikan bantuan kepada seseorang yang mengalami kesulitan dalam hidupnya, supaya orang tersebut mampu mengatasinya sendiri karena timbul kesadaran atau penyerahan diri kepada Tuhan YME. Sehingga timbul pada dirinya suatu cahaya harapan kebahagiaan hidup sekarang dan masa depan. ${ }^{14}$

Untuk itu, bimbingan dan konseling Islam dapat diartikan sebagai suatu proses pemberian bantuan kepada individu untuk belajar mengembangkan fitrahnya yakni iman, akal dan kemauan agar mampu hidup selaras dengan ketentuan dan petunjuk Allah SWT. Pada dasarnya manusia memiliki dua potensi hubungan, selain mereka merupakan makhluk sosial atau hidup dengan orang lain, manusia juga mempunyai hubungan dengan Allah, akan tetapi terkadang manusia tidak dapat mengoptimalkan hubungan tersebut, sehingga tidak jarang dari mereka mengalami kekosongan pada hatinya yang harus akan sentuhan rohani, di sinilah peran bimbingan dan konseling Islam sebagai usaha pemberian bantuan menyeluruh pada diri individu yang bermasalah.

${ }^{13}$ Samsul MunirAmin, Bimbingan dan Konseling Islam, Jakarta: AMZAH, 2010, hlm. 23

${ }^{14}$ Arifin, Pokok-Pokok Pikiran Tentang Bimbingan dan Penyuluhan Agama, Jakarta: Bulan Bintang, 1976,hlm. 24 
Sedangkan landasan bimbingan dan konseling Islam yaitu Al-Quran dan Sunah Rasul, sebab keduanya merupakan sumber dari segala sumber pedoman kehidupan umat Islam. Al-Qur'an dan sunah Rasul dapat diistilahkan sebagai landasan ideal dan konseptual bimbingan dan konseling Islam. ${ }^{15}$ Sebagai firman-firman Allah yang terkandung dalam AlQur'an dan Sabda-sabda sebagai landasan bimbingan dan konseling Islam, yaitu surat Ali-Imran ayat 104 sebagai berikut:

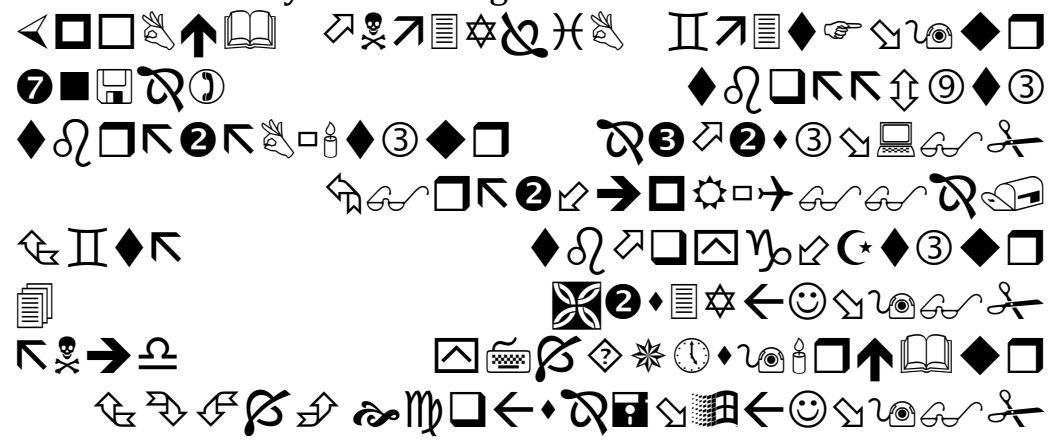

"Dan Hendaklah ada diantara Kamu Segolongan Umat yang Menyeru kepada Kebajikan, Menyuruh kepada yang Ma'ruf dan Mencegah dari yang Munkar Merekalah Orang-orang yang Beruntung". 16

Pada surat Ali-Imran ayat 104, Allah memerintahkan orang yang beriman untuk mengajak orang lain menempuh jalan kebajikan dan ma'ruf. Nilai-nilai yang terkadang dalam ajaran Islam disampaikan secara persuasif dalam bentuk ajaran yang baik. Dasar yang bersumber dari hadist yaitu menurut An-Nawawi Imam Abu Zakariya Yahya bin Syarf Terjemah Riyadhus Shalikin Jilid I' ${ }^{17}$ dituliskan sebagai berikut:

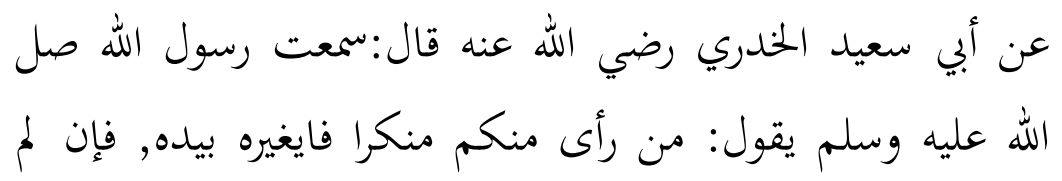

15 Aunur RahimFaqih,, Bimbingan dan Konseling dalam Islam, Yogjakarta: UI Press, 2001, hlm.5

16Departemen Agama RI, Al-Qur'an dan Terjemah, Jakarta: Al-Jumanatul, 2004, hlm. 63

17 An-Nawawi Imam Abu Zakariya Yahya bin Syarif, Terjemahan Riyadhus Shalikin Jilid I, Bandung: Al-Ma'arif, 1987, hlm.197 


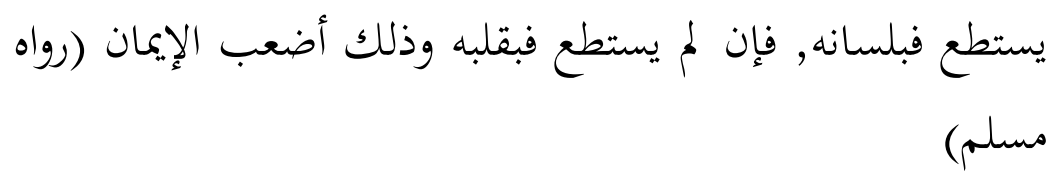

"Barang siapa di antara kamu melihat kemungkaran maka hendaklah ia merubah dengan tangannya, jika tidak kuasa maka dengan lisannya, jika tidak kuasa dengan lisannya maka dengan hatinya, yang demikian itu adalah selemah-lemahnya iman" (HR.Muslim).

Hadist Riwayat Muslim ini mengandung isi bahwa merubah perilaku yang batil atau tidak baik adalah kewajiban yang dituntut dalam ajaran agama Islam untuk setiap umat sesuai dengan kemampuan dan kekuatannya. Merubah dengan hati merupakan selemah-lemahnya iman, setelah tangan dan lisan kita tak mampu untuk merubah perilaku munkar tersebut. Dengan maksud, ketika seorang siswa sudah tidak bisa di toleransi kenakalannya, maka seorang guru tidak bisa memaksakan kehendaknya.

\section{b) Tujuan dan Fungsi Bimbingan dan Konseling Islam}

Tujuan yang ingin dicapai bimbingan dan konseling Islam, menurut Anwar Sutoyo ${ }^{18}$ yaitu agar fitrah yang dikaruniakan Allah kepada individu bisa berkembang dan berfungsi dengan baik, sehingga menjadi pribadi yang khaffah, dan secara bertahap dapat mengaktualisasikan apa yang diimaninya itu dalam kehidupan sehari-hari, yang tampil dalam melaksanakan tugas kekhalifahan di bumi, dan ketaatan dan beribadah dengan mematuhi segala perintah-Nya dan menjauhi segala larangan-Nya.

Secara umum, bimbingan dan konseling bertujuan untuk mencari jati diri dalam bentuk perubahan diri (sikap dan tingkah laku) dan mengembangkan kemampuan serta potensi yang dimilikinya untuk bertahan hidup di lingkungan, sekolah maupun masyarakat. Sedangkan menurut Prayetno dan Amti ${ }^{19}$, tujuan bimbingan dan konseling yaitu untuk membantu individu mengembangkan potensinya seoptimal mungkin. Berarti bimbingan konseling membantu individu untuk menjadi insan yang

18 AnwarSutoyo, Bimbingan dan Konseling Islam (Teori dan Praktik), Yogyakarta: Pastaka Belajar, 2013, hlm. 20 hlm.104

19 Prayetno dan Erman Amti, Dasar-dasar Bimbingan dan Konseling, Jakarta: 2008, 
berguna dalam kehidupannya yang memiliki berbagai wawasan, pandangan, interpretasi, pilihan, penyesuaian dan keterampilan yang tepat berkenaan dengan diri sendiri dan lingkungannya.

Sedangkan tujuan bimbingan dan konseling Islam baik secara umum maupun Islam memiliki fungsi yang sama, yakni: 1) fungsi preventif, yaitu usaha pencegahan terhadap timbulnya masalah. Dalam fungsi pencegahan ini layanan yang diberikan berupa bantuan bagi individu agar terhindar dari berbagai masalah yang dapat menghambat perkembangannya. 2) fungsi korektif, yaitu membantu individu memecahkan masalah yang sedang dihadapi atau dialaminya. 3) fungsi preservatif, yaitu membantu individu menjaga agar situasi dan kondisi yang telah menjadi baik (terpecahkan) tidak menimbulkan masalah kembali. 4) fungsi develompental, yaitu membantu individu memelihara dan mengembangkan situasi dan kondisi yang telah baik agar tetap baik, sehingga tidak memungkinkannya menjadi sebab munculnya masalah baginya. ${ }^{20}$

Apabila fungsi-fungsi Bimbingan dan Konseling Islam di atas dihubungkan dengan penanaman kedisiplinan shalat dhuha pada anak hiperaktif, maka akan menjadi sebagai berikut: fungsi yang pertama preventif; yakni membantu individu menjaga atau mencegah terjadi tidak kedisiplinan anak hiperaktif ketika melaksanakan ibadah shalat dhuha berjamaah. Kedua, fungsi kuratif atau korektif; yakni membantu individu memecahkan masalah yang sedang dialami. Ketiga, fungsi preservatif; yakni membantu individu menjaga agar situasi dan kondisi psikologis yang kacau atau mengalami gangguan menjadi baik kembali. Keempat, fungsi developmental atau pengembangan: yakni membantu individu mengembangkan potensi yang ada dalam dirinya sehingga diharapkan dia dapat hidup sebagaimana semestinya.

\section{c) Metode Bimbingan dan Konseling Islam}

Metode dapat di artikan sebagai sesuatu yang digunakan untuk mengungkapkan cara yang paling cepat dan tepat dalam melakukan sesuatu. Metode bimbingan secara umum antara lain: metode wawancara, bimbingan kelompok. Metode yang dipusatkan pada klein, dan metode pencerahan. ${ }^{21}$ Bimbingan dan konseling Islam, menurut Faqih ${ }^{22}$

20 Faqih, Aunur Rahim, Bimbingan dan Konseling dalam Islam, Yogjakarta: UI Press, 2001, hlm.37

${ }^{21}$ Amin, Samsul Munir, Bimbingan dan Konseling Islam, Jakarta: AMZAH, 2010, hlm.69 
diklasifikasikan berdasarkan segi komunikasi terbagi menjadi dua yaitu metode komunikasi langsung atau disingkat metode langsung, metode komunikasi tidak langsung atau metode tidak langsung. Sedangkan menurut Ulwan (1981: 2) menyebutkan ada lima metode pembinaan keagamaan untuk anak yaitu sebagai berikut:

1) Metode Keteladanaan

Pemberian keteladanan kepada anak-anak dalam hal ini adalah guru-guru dan orang tua. keteladanan memberikan pengaruh yang besar dari pada nasehat. Karena anak memiliki sifat yang cenderung mencontoh apa yang mereka lihat. Keteldanan memberikan dampak positif yaitu meniru apa yang di lihatnya dan membentuk kepribadian yang baik kepada anak. Pemberian keteladanan kepada anak-anak dalam hal ini pembimbing maupuun guru harus mampu menjadi contoh bagi anak didiknya, artinya yaitu segala tingkah laku dan perbuatan pembimbing dan guru merupakan keteladanan yang baik bagi anak

2) Metode Pembiasaaan

Metode pembiasaan merupakan sebuah cara yang dipakai oleh guru pembimbing untuk membiasakan anak didiknya untuk mengerjalan suatu kebaikan secara berulang-ulang. Sehingga menjadi kebiasaan yang sulit untuk ditinggalkan. Adapun beberapa bentuk pembiasaan yang diterapkan kepada anak antara lain: pertama, Pembiasaan dengan akhlak yaitu berupa pembiasaan bertingkah laku baik, yang dilakukan baik di dalam sekolah maupun di luar sekolah. Kedua, Pembiasaan dalam ibadah yaitu pembiasaan yang berhubungan dengan ibadah dalam islam, seperti shalat berjamaah di masjid, mengucapkan bismilah dan hamdalah saat memulai dan mengakhiri sesuatu kegiatan. Dan membaca asmaul husna bersama-sama pada pagi hari sebelum pembelajaran dan lain sebagainya. Ketiga, Pembiasaab dalam keimanan yaitu berupa pembiasaan agar anak beriman dengan sepenuh hati, dengan membawa anak untuk memperhatikan alam semesta, mengajak anak untuk merenungkan dan memikirkan tentang seluruh ciptaan di langit dan di bumi dengan secara bertahap. (Ramayulis, 2005: 100).

3) Metode nasehat

Metode lain yang penting dalam pendidikan, pembentukan keimanan, mempersiapkan moral, spritual dan sosial anak, adalah

22 Faqih, Aunur Rahim, Bimbingan dan Konseling dalam Islam, Yogjakarta: UI Press, 2001, hlm.53 
pendidikan dengan pemberian nasehat. Sebab, nasehat ini dapat membukakan mata anak-anak pada hakekat sesuatu luhur, dan menghiasinya dengan akhlak yang mulia, dan membekalinya dengan prinsip-prinsip .

4) Metode penyadaran atau pemberian perhatian

Yang dimaksud dengan pendidikan dengan perhatian adalah mencurahkan, memperhatikan dan senantiasa mengikuti perkembangan anak dalam pembinaan akidah dan moral, persiapan spiritual dan sosial, di samping selalu bertanya tentang situasi pendidikan jasmani dan daya hasil ilmiahnya. Tidak diragukan, bahwa pendidikan ini dianggap sebagai asas terkuat dalam pembentukan manusia secara utuh, yang menunaikan hak setiap orang yang memiliki hak dalam kehidupan, termasuk mendorongnya untuk menunaikan tanggungjawab dan kewajiban secara sempurna.

5) Metode hukuman

Metode pengawasan terhadap anak dilakukan secara terus menerus perkembangan mereka mengenai aspek-aspek pengetahuan dan sikap. Pengawsan bisa disertai pendampingan anak dalam upaya membentuk aqidah, moral dan mengawasinya secara spikis dan sosialnya serta menanyakan secara terus menerus tentang keadaan jasmani maupun belajarnya.

\section{d) Kedisiplinan Shalat Dhuha}

1) Pengertian Kedisiplinan

Kedisiplinan berasal dari kata disiplin yang mendapat awalan "ke" dan akhiran "an" menurut Kamus Besar Bahasa Indonesia (KBBI), disiplin mempunyai arti ketaatan dan kepatuhan pada aturan, tata tertib dan lain sebagainya. ${ }^{23}$

Sedangkan Disiplin adalah suatu tata tertib yang dapat mengatur tatanan kehidupan pribadi dan kelompok (Djamarah, 2002: 12). Maka dapat disimpulkan bahwa penanaman disiplin adalah penyesuaian antara sikap dan tingkah laku seseorang dengan peraturan yang sedang diberlakukan sehingga untuk mewujudkan disiplin dalam diri siswa diperlukan adanya tata tertib.

2) Fungsi Disiplin

23Departemen Pendidikan Nasional, RI, Kamus Besar Bahasa Indonesia, (Edisi Ketiga), Jakarta: Balai Pustaka, 2005, hlm.747 
Fungsi disiplin menurut Tulus Tu'u diantaranya sebagai berikut: a) Menata kehidupan bersama; b) Membangun kepribadian; c) Melatih kepribadian; d) Menciptakan lingkungan yang kondusif; 24

3) Pengertian Shalat Dhuha

Menurut Zakiah (1988: 55) shalat dhuha sebagai shalat sunah yang waktunya dimulai dari matahari naik kira-kira pukul 07.00 WIB, sampai menjelang matahari tegak lurus di atas bumi (sebelum waktu dzuhur datang). ${ }^{25}$ Sedangkan menurut Alim (2009: 49) mengemukakan bahwa shalat dhuha adalah ibadah sunah yang dilakukan pada waktu pagi hari atau waktu dhuha. Sedangkan shalat dhuha menurut Rifa'i (2008: 85) yaitu shalat sunah yang dikerjakan pada waktu matahari naik. Waktu dhuha adalah waktu ketika matahari mulai naik kurang lebih 7 hasta sejak terbitnya (kira-kira pukul tujuh pagi) hingga waktu dzuhur.

Dari uraian di atas dapat disimpulkan bahwa shalat dhuha adalah salat sunah yang dilaksanakan pada waktu pagi hari yaitu antara pukul 07.00-11.00 WIB, pada saat matahari sudah bersinar siang sampai saat matahari naik mendekati waktu dzuhur.

4) Tata cara Shalat Dhuha

Ttata cara shalat dhuha hampir sama dengan sholat sunah pada umumnya, yaitu: a) Membaca niat shalat dhuha; b) Setelah membaca niat kemudian membaca takbir; c) Membaca doa iftitah; d) Membaca surat al-fatihah; e) Membaca surat-surat pendek (Juz Amma) atau surat Al-Quran. Dan lebih afdholnya rakaat pertama membaca surat AsySyam dan rakaat kedua surat Ad-Dhuha; f) Ruku' dan membaca tasbih tiga kali; g) I'tidal dan membaca bacaan tasbih tiga kali; h) Sujud kedua dan membaca tasbih tiga kali; i) Duduk diantara dua sujud dan membaca bacaannya; Sujud kedua membaca tasbih tiga kali; 26

Setelah rakaat pertama selesai, lakukan rakaat kedua sebagaimana cara di atas, kemudian tasyahhud akhir setelah selesai maka membaca selama dua kali. Rakaat-rakaat selanjutnya dilakukan sama seperti contoh di atas. 2004, hlm.32

${ }^{24}$ Tu'u, Tulus, Peran Disiplin pada Perilaku dan Prestasi Siswa, Jakarta: Grasindo,

${ }^{26}$ Rifa'i, Mohamad, Risalah Tuntunan Shalat Lengkap, Semarang: PT. Thoha Putra, 2015, hlm 84 . 


\section{e) Anak Hiperaktif}

1) Pengertian Anak Hiperaktif

Menurut pendapat Eric Taylor, kata "hiperaktivitas" (hiperaktivity) digunakan untuk menyatakan suatu pola perilaku pada seseorang yang menunjukkan sikap tidak mau diam, tidak menaruh perhatian dan impulsif (semau gue). ${ }^{27}$ Menurut Ferdinand Zeviera, anak hiperaktif yaitu anak yang mengalami gangguan pemusatan perhatian dengan hiperaktivitas kondisi ini juga disebut sebagai gangguan hiperkinetik. Dahulu kondisi ini sering disebut sebagai minimal brain dysfunction syndrome. Gangguan hiperkinetik adalah gangguan pada anak yang timbul pada masa perkembangan dini. Dengan ciri utama tidak mampu memusatkan perhatian, hiperaktif dan impulsif. Ciri perilaku ini mewarnai berbagai situasi dan dapat berkelanjutan hingga dewasa. ${ }^{28}$

Menurut Seto Mulyadi dalam bukunya Irwati Ismail (2009) yang berjudul "Mengatasi Problem Anak Sehari-hari" mengatakan pengertian istilah anak hiperaktif. Anak hiperaktif adalah hiperaktif menunjukkan adanya suatu pola perilaku yang menetap pada seorang anak. Perilaku yang ditandai dengan sikap tidak mau diam, tidak bisa berkonsentrasi dan bertindak sekehendak hatinya atau impulsif. Hiperaktivitas juga mengacu ketiadaannya pengendalian diri, misalnya mengambil keputusan tanpa memikirkan akibat-akibat yang mungkin timbul, dan sering menyebabkan pelakunya terkena hukuman atau mengalami kecelakaan. ${ }^{29}$

2) Faktor Penyebab Hiperaktif

Secara umum anak hiperaktif memiliki tingkat kesehatan fisik yang tidak sebaik anak lain. Beberapa gangguan seperti asma, alergi, dan infeksi tenggorokan sering dijumpai. Pada saat tidur biasanya juga tidak setenang anak-anak lain. Banyak anak hiperaktif yang sulit tidur dan sering terbangun pada malam hari. Selain itu, tingginya tingkat aktivitas fisik anak juga beresiko tinggi untuk mengalami kecelakaan seperti terjatuh, terkilir, dan sebagainya.Berikut ini adalah faktor-

\footnotetext{
27 Taylor, Erik, Anak yang Hiperaktif, Jakarta: Gramedia, 1992, hlm. 2

${ }^{28}$ Zeviera, Ferdinand, Anak Hiperaktif Cara Cerdas Menghadapi Anak Hiperaktif dan Gangguan Konsentrasi, Yogyakarta: Ar-Ruzza, 2007, hlm.11

29 Ismail, Irawati, Mengatasi Problem Anak Sehari-hari, Jakarta: PT Gramedia Pustaka Utama, 2009, hlm 56
} 
faktor penyebab hiperaktif pada anak (Isnanto, 2013: 89) antara lain sebagai berikut :

Pertama, faktor neurologik, Insiden hiperaktif yang lebih tinggi didapatkan pada bayi yang lahir dengan masalah-masalah prenatal seperti lamanya proses persalinan, distres fetal, persalinan dengan cara ekstraksi forcep, toksi miagravidarum dibandingkan dengan kehamilan dan persalinan normal. Di samping itu faktor-faktor seperti bayi yang lahir dengan berat badan yang rendah, ibu yang terlalu muda, ibu yang merokok dan minum alkohol juga meninggikan insiden hiperaktif.

Kedua, faktor toksik, Beberapa zat makanan seperti salisilat dan bahan-bahan pengawet memiliki potensi untuk membentuk perilaku hiperaktif pada anak. Di samping itu, kadar timah dalam serum darah anak yang meningkat, ibu yang merokok dan mengkonsumsi alkohol, terkena sinar X pada saat hamil juga dapat melahirkan calon anak hiperaktif.

Ketiga, faktor genetic, didapatkan korelasi yang tinggi dari hiperaktif yang terjadi pada keluarga dengan anak hiperaktif. Kurang lebih sekitar $25-35 \%$ dari orang tua dan saudara yang masa kecilnya hiperaktif akan menurun pada anak. Hal ini juga terlihat pada anak kembar.

Keempat, faktor kultural dan psikososial; 1) Pemanjaan; 2) Kurang disiplin dan pengawasan; 3) Orientasi kesenangan; 4) Hukuman; 30

3) Penanganan Anak Perilaku Hiperaktif

Karakter utama yang harus dimiliki seorang guru dalam menangani anak yang berperilaku hiperaktif adalah fleksibilitas dan sensivitas yaitu luwes dan terbuka, punya empati yang tinggi dan mau menyesuaikan diri dengan masalah yang dialami anak. Ia harus memahami bahwa rentang perhatian anak yang mengalami gangguan hiperaktif lebih singkat dari pada anak-anak yang lain, sehingga dalam proses pembelajaran atau pada aktifitas lainnya tidak disamakan dengan anak yang lain. Selain itu seorang guru harus mampu mengolah pembelajaran secara profesional.

Menurut Douchcty (1990: 67) beberapa jenis bantuan yang dapat dilakukan oleh guru dalam menangani anak yang berperilaku hiperaktif di antaranya: 
Pertama, menempatkan posisi duduk pada bagian depan berhadapan dengan guru, membelakangi anak-anak yang lain agar dapat mudah perhatian beralih pada hal-hal yang lain, atau menempatkan pada posisi yang memungkinkan berdiri selama pelajaran tanpa mengganggu anak-anak lain misalnya posisi dekat dinding, atau menyiapkan kursi kosong di dekatnya.

Kedua, pemberian informasi atau penjelasan harus jelas dengan menggunakan media pembelajaran yang bervariasi dan dilakukan secara klasikal untuk semua anak dan dilanjutkan dengan individual untuk anak yang hiperaktif, penjelasan harus jelas, kongkrit, singkat dengan menggunakan kontak mata langsung pada saat pengajaran.

Ketiga, memanfaatkan energi anak dengan tugas lain yang dapat menguras tenaganya, misalnya memberi tugas menghapus white board, mengajak anak bermain peran dengan pentas kecil-kecilan, membawa anak ke tempat wisata (dalam pembelajaran ada unsur pergerakan tubuh) ini dimaksudkan agar energi anak dapat tersalurkan.

Keempat, konsultasi dengan pihak yang lebih profesional, dengan maksud memperoleh keterampilan atau teknis dalam membantu mengatasi masalah anak yang berperilaku hiperaktif.

Untuk melatih anak agar fokus, ciptakan suasana yang kondusif jangan tekan dia, terima keadaan apa adanya, perlakukan anak dengan hangat dan sabar, tapi konsisten dan tegas di dalam menerapkan norma dan tegas. Adapun upaya yang dilakukan guru dengan pemberian hukuman untuk merubah perilaku anak hiperaktif sebaiknya tidak dilakukan. Guru harus memahami bahwa anak hiperaktif bukan tidak mau mematuhi aturan yang ada tetapi ia tidak mampu melakukannya karena adanya permasalahan perhatian yang dialami. Anak hiperaktif sangat mudah kecewa dan merasa rendah diri, tetapi apabila mendapat sambutan atau penghargaan atas perilaku positif yang dilakukan maka perkembangan pribadinya akan lebih terarah, dan bila tidak mendapat sambutan atau penghargaan maka ia akan menjadi rendah diri dan egoisnya makin tinggi dan akan bersifat masa bodoh. Oleh yaitu pemberian penghargaan atau pujian sangat diharapkan untuk dilakukan oleh guru atau pendidik lainnya.

Menurut Wiramiharja bahwa, anak yang hiperaktif cenderung lebih patuh terhadap penyelesaian tugas dan merubah perilakunya, jika ia memperoleh pujian atau penguatan karena melakukannya. Pemberian sanksi bukan berarti tidak efektif jika digunakan dengan 
cara yang lebih positif. ${ }^{31} \mathrm{Hal}$ tersebut diperkuat juga Pentecost (2004: 69) pujian adalah salah satu cara yang paling efektif untuk menolong anak agar berubah, pujian yang diberikan secara jelas dan sering merupakan senjata rahasia anda terhadap aspek perilaku negatif anak yang berperilaku hiperaktif. Namun perlu diingat bahwa di dalam memberikan imbalan upayakan pujian itu bervariasi agar anak tidak merasa bosan.

\section{Analisis Karakteristik Anak Hiperaktif dan Metode Bimbingan dan Konseling Islam dalam Menanamkan Kedisiplinan Shalat dhuha pada Anak Hiperaktif}

\section{Analisis Karakteristik Anak Hiperaktif di MI Nurul Islam Ngaliyan Semarang}

Hal yang tidak boleh diabaikan dalam pendidikan anak adalah mengetahui karakter mereka terlebih dahulu, agar tidak terjadi salah paham dalam praktek dan prosesnya. Kesalahan dalam penggunaan pendekatan, media, metode dan strategi pembelajaran yang tidak tepat dikarenakan kesalahan dalam memahami karakter anak. Begitu pula terhadap anak hiperaktif, hal yang penting untuk diketahui adalah karakter anak hiperaktif.

Hasil observasi yang dilakukan peneliti mengenai karakteristik anak hiperaktif di MI Nurul Islam Ngaliyan Semarang terdapat tiga anak yang termasuk kriteria anak hiperaktifyaitu anak yang tidak bisa diam, selalu bergerak kesana-kesini ketika berada di kelas, seringkali gelisah, tidak bisa fokus, hal ini tampak ketika dia diajak bicara, belajar dan sebagainya. Kurang perhatian terhadap sesuatu, hal ini tampak ketika dia sering kehilangan barang atau benda penting lainnya. Dia juga kurang sabar menunggu giliran dan sering menyela pembicaraan orang lain"32

Menurut Bandi Delphie (2009: 11),mendefinisikan anak hiperaktif sebagai berikut: "Hyperactive child syndrome, typically a child with this syndrome is continually a motion, cannot concentrate for more than a moment, acts and speaks on impulse, is impatient and easily upset. At home, he is constantly in trouble of his restlessness, noisiest, and disobedience. In hlm.9

31Wiramiharjo, Pengantar Psikologi Abnormal, Bandung: PT. Refika Aditama, 2008,

32 Hasil observasi, tanggal 08 agustus 2015 
school, he is readly distracted, rarely finishes his work, tends to clown and talk out of turn in class and becomes labeled a discipline problems" ${ }^{\prime 3}$

Untuk mengetahui karakteristik anak hiperaktif dapat dilihat dari perilaku anak yang tidak bisa diam. Duduk dengan tenang merupakan sesuatu yang sulit dilakukan. Mereka akan bangkit dan berlari-lari, berjalan kesana-kemari. Untuk dapat disebut memiliki karakteristik hiperaktif harus ada tiga utama yang tampak dalam perilaku seorang anak yaitu inatensi, hiperaktif dan impulsif. Inatensi atau pemusatan perhatian yang kurang dapat dilihat dari kegagalan seorang anak dalam memberikan perhatian secara utuh terhadap sesuatu. Gejala hiperaktif dapat dilihat dari perilaku anak yang tidak bisa diam. Gejala impulsif ditandai dengan kesulitan anak untuk menunda respon. ${ }^{34}$

Berdasarkan instrumen Diagnostic And Statistical Manual-IV Task Force (DSM-IV TR), anak hiperaktif terdiri atas tiga tipe berdasarkan gejalagejalanya, yaitu kurang pemusatan perhatian (Inattention), selalu gelisah dan tidak mau diam atau selalu bergerak secara terus menerus (Hyperactivity), serta suka menuruti kata hati atau kesulitan menunda respon (Impulsivity).

Setelah melaksanakan observasi, peneliti dapat menyimpulkan bahwa karakteristik anak hiperaktif di MI Nurul Islam Ngaliyan Semarang, yaitu sebagai berikut:

\begin{tabular}{|l|l|l|l|l|}
\hline No & \multicolumn{1}{|c|}{$\begin{array}{l}\text { Nama } \\
\text { Siswa }\end{array}$} & \multicolumn{1}{|c|}{ Inattention } & Hyperactivity & \multicolumn{1}{|c|}{ Impulsivity } \\
\hline 1 & $\begin{array}{l}\text { Anak } \\
\text { Inisial “H” }\end{array}$ & $\begin{array}{l}\text { Sering mengalami } \\
\text { kesulitan dalam } \\
\text { memusatkan } \\
\text { perhatian } \\
\text { terhadap tugas- } \\
\text { tugas atau } \\
\text { kegiatan bermain. }\end{array}$ & $\begin{array}{l}\text { Sering } \\
\text { berbicara } \\
\text { berlebihan }\end{array}$ & $\begin{array}{l}\text { Sering } \\
\text { memberi } \\
\text { jawaban } \\
\text { sebelum } \\
\text { pertanyaan } \\
\text { selesai. }\end{array}$ \\
\hline 2 & Anak & $\begin{array}{l}\text { Sering tidak } \\
\text { mengikuti baik- } \\
\text { baik instruksi dan } \\
\text { gagal dalam } \\
\text { menyelesaikan } \\
\text { pekerjaan sekolah, }\end{array}$ & $\begin{array}{l}\text { Sering } \\
\text { meninggalkan } \\
\text { tempat duduk } \\
\text { di dalam kelas } \\
\text { atau dalam } \\
\text { situasi lainnya }\end{array}$ & $\begin{array}{l}\text { Sering } \\
\text { menginterupsi } \\
\text { atau } \\
\text { mengganggu } \\
\text { orang lain, } \\
\text { misalnya }\end{array}$ \\
\hline
\end{tabular}

33Bandi Deiphie, Layanan Perilaku Hiperaktif, Klaten: PT. Insani, 2009, hlm.11

${ }^{34}$ Hasil wawancara dengan bapak hadi, tanghal 08 agustus 2016 


\begin{tabular}{|c|c|c|c|c|}
\hline No & $\begin{array}{l}\text { Nama } \\
\text { Siswa }\end{array}$ & Inattention & Hyperactivity & Impulsivity \\
\hline & & $\begin{array}{l}\text { pekerjaan atau } \\
\text { tugas di tempat } \\
\text { kerja bukan } \\
\text { (bukan } \\
\text { disebabkan karena } \\
\text { perilaku melawan } \\
\text { atau kegagalan } \\
\text { untuk mengerti } \\
\text { instruksi) }\end{array}$ & $\begin{array}{l}\text { dimana } \\
\text { diharapkan } \\
\text { agar anak tetap } \\
\text { duduk. }\end{array}$ & $\begin{array}{l}\text { memotong } \\
\text { pembicaraan } \\
\text { atau } \\
\text { permainan. }\end{array}$ \\
\hline 3 & $\begin{array}{l}\text { Anak } \\
\text { Inisial "Y" }\end{array}$ & $\begin{array}{l}\text { Sering kali gagal } \\
\text { memperhatikan } \\
\text { baik-baik terhadap } \\
\text { sesuatu yang } \\
\text { detail atau } \\
\text { membuat } \\
\text { kesalahan yang } \\
\text { sembrono dalam } \\
\text { pekerjaan sekolah } \\
\text { dan kegiatan- } \\
\text { kegiatan. }\end{array}$ & $\begin{array}{l}\text { Sering } \\
\text { mengalami } \\
\text { kesulitan } \\
\text { dalam bermain } \\
\text { atau terlibat } \\
\text { dalam kegiatan } \\
\text { senggang } \\
\text { secara terang. }\end{array}$ & $\begin{array}{l}\text { Sering } \\
\text { mengalami } \\
\text { kesulitan } \\
\text { menanti giliran }\end{array}$ \\
\hline
\end{tabular}

(hasil Observasi, dengan wali kelas IIA/B/C, tanggal 08 Agustus 2016). ${ }^{35}$

Pada dasarnya perilaku hiperaktifitas pada anak hiperaktif tidak bisa disembuhkan namun bisa di kurangi. Menangani anak hiperaktif memang membutuhkan kesabaran yang luar biasa. Karakter utama yang harus dimiliki seorang guru dalam menangani anak yang berperilaku hiperaktif adalah fleksibilitas dan sensivitas yaitu luwes dan terbuka, punya empati yang tinggi dan mau menyesuaikan diri dengan masalah yang dialami anak atau menerima kondisi anak.

Guru harus memahami bahwa rentang perhatian anak yang mengalami gangguan hiperaktif lebih singkat dari pada anak-anak yang lain, sehingga dalam proses pembelajaran atau pada aktifitas lainnya seperti shalat dhuha berjamaah, agar tidak disamakan dengan anak yang lain. Selain itu seorang guru harus mampu mengolah pembelajaran secara

35 Hasil observasi,tanggal 08 agusstus 2016. 
profesional atau semenarik mungkin agar anak hiperaktif dapat tertarik mau memperhatikan dan bisa berkonsentrasi dengan baik. ${ }^{36}$

Dari hasil observasi yang peneliti lakukan di MI Nurul Islam Ngaliyan Semarang. Dalam menangani perilaku anak hiperaktif yaitu menggunakan cara menempatkanposisi duduk pada bagian depan berhadapan dengan guru. Memberikan informasi yang jelas, konkrit, singkat dengan menggunakan kontak mata langsung pada saat pengajaran, memanfaatkan energi anak dengan tugas atau ke hal-hal yang positif, setelah itu melakukan konsultasi dengan pihak yang lebih profesional. Sedangkan untuk melatih kefokusan pada anak hiperaktif. Guru harus menciptakan suasana yang kondusif jangan tekan dia, terima keadaannya, perilaku anak dengan sabar dan hangat, dan konsisten (hasil observasi, tanggal 16 Agustus 2016).

Guru harus mengetahui memahami bahwa anak hiperaktif bukan tidak mau mematuhi aturan yang ada tetapi ia tidak mampu melakukannya karena adanya permasalahan perhatian yang dialami. Anak hiperaktif sangat mudah kecewa dan merasa rendah diri, tetapi apabila mendapat sambutan atau penghargaan atas perilaku positif yang dilakukan maka perkembangan pribadinya akan lebih terarah, dan bila tidak mendapat sambutan atau penghargaan maka meraka akan menjadi rendah diri dan egoisnya makin tinggi dan akan bersifat masa bodoh.Oleh karena itu pemberian penghargaan atau pujian sangat diharapkan untuk dilakukan oleh guru atau pendidik lainnya. Hal ini yang menyebabkan anak menjadi anak hiperaktif. Sehingga di butuhkan perhatian yang lebih kepada anak hiperaktif, di sambut dengan hangat dan diberi penghargaan atau pujian agar hati anak hiperaktif merasa senang dan bisa berkembang dengan baik. $^{37}$

Sehingga anak hiperaktif ini membutuhkan perhatian yang lebih baik dari keluarga, guru, teman dan orang yang ada di sekitarnya. Ketika anak hiperaktif ini dianggap dan di beri pujian, sanjungan atau penghargaan maka sifat anak hiperaktif ini berkurang dan bisa berkembang dengan terarah dan dapat menyesuaikan keadaan lingkungan. Dengan mengetahui mengapa anak tersebut menjadi anak hiperaktif maka sifat guru menerima kondisi anak tersebut, memperbaiki perilaku anak atau mengurangi keaktifan pada anak hiperaktif dan melakukan observasi sederhana, sehingga bisa menanamkan jiwa keagamaan pada anak hiperaktif yaitu

\footnotetext{
36 Hasil wawancara dengan wali kelas, tanggal 08 agustus 2016

37 Hasil wawancara dengan wali kelas, tanggal 16 agustus 2016
} 
salah satunya dengan menanamkan kedisiplinan shalat dhuha berjamaah pada anak hiperaktif (hasil observasi, tanggal 16 Agustus 2016).

\section{Analisis Metode Bimbingan dan Konseling Islam dalam Menanamkan Kedisiplinan Shalat dhuha pada Anak Hiperaktif di MI Nurul Islam Ngaliyan Semarang}

Pada dasarnya manusia sudah dibekali dengan potensi iman dalam dirinya, namun terkadang banyak orang yang tidak bisa menggunakannya atau menyalah gunakanan potensi tersebut. Oleh karena itu dibutuhkan sasaran dari bimbingan dan konseling Islam untuk menyadarkan potensi yang telah dimiliki, sedangkan bimbingan dan konseling Islam merupakan proses pemberian bantuan terarah, kontinu, dan sistematis kepada setiap individu agar ia dapat mengembangkan potensi yang telah mereka miliki, dan selaras landasan bimbingan dan konseling Islam yaitu Al-Quran dan Hadist sehingga bisa hidup bahagia di dunia dan di akhirat.

Dari pemaparan di atas dapat diketahui bahwa pemberian bimbingan kepada manusia sangatlah penting. Seperti halnya pemberian bimbingan shalat. Karena shalat merupakan kewajiban bagi setiap muslim yang beriman. Terdapat dua jenis shalat yaitu shalat wajib dan shalat sunah. Shalat sunah terdiri berbagai macam, dan salah satunya yaitu shalat dhuha. Shalat dhuha dilaksanakan pada pagi hari antara pukul 07.00 WIB sampai pukul 10.00 WIB. Jumlah rakaat shalat dhuha minimal dua rakaat dan maksimal dua belas rakaat dengan satu salam setiap dua rakaat. ${ }^{38}$

Salah satu model bimbingan dan konseling Islam yaitu salah satunya dengan melaksanakan shalat dhuha di MI Nurul Islam Ngaliyan Semarang, pelaksanan shalat dhuha berjamaah bisa berjalan dengan baik maka, tidak lepas dari kerjasama antara wali kelas dan guru bimbingan dan konseling. Wali kelas sendiri merupakan tokoh kunci dalam kegiatan-kegiatan bimbingan yang sebenarnya di dalam kelas. Guru selalu dalam hubungan yang erat dengan murid, guru kelas banyak mempunyai kesempatan untuk mempelajari murid, mengawasi tingkah laku dan kegiatannya, dan apabila mereka teliti serta menaruh perhatian mereka akan mengetahui sifat-sifat murid, kebutuhannya, minatnya, masalah-masalahnya, dan titik kelemahan serta kekuatannya. ${ }^{39}$

\footnotetext{
${ }^{38}$ Rifa'i, Mohamad, Risalah Tuntunan Shalat Lengkap, Semarang: PT. Thoha Putra, 2015,hlm.64

${ }^{39}$ Hasil wawancara dengan wali kelas, tanggal 16 agustus 2016
} 
Dalam hal ini guru bimbingan dan konseling yang diharapkan memiliki pengetahuan dan pengertian yang lebih lengkap mengenai kepribadian murid-murid serta teknik-teknik diagnostik dan memiliki waktu lebih banyak untuk wawancara, menghadapi kasus-kasus yang perlu mendapatkan perhatiannya segera, akan tetapi pada kenyataannya guru bimbingan dan konseling sering menemukan kesulitan dalam mengenalinya sehingga membutuhkan pertolongan pihak lain.

Hubungan kerjasama antara wali kelas dan guru bimbingan dan konseling merupakan kerjasama yang diatur dan dilaksanakan di MI Nurul Islam Ngaliyan Semarang. Dalam kerjasama ini, kerja wali kelas lebih kepada hal-hal yang bersifat teknis yaitu bersifat isi dari kegiatan yang diselenggarakan. Sedangkan peran guru bimbingan dan konseling yaitu sebagai penelitian pelaksanaan dan membantu agar kegiatan yang diselenggarakan dapat berjalan secara efektif dan efisien, sedangkan metode yang digunakan dalam menanamkan kedisiplinan shalat dhuha pada anak hiperaktif menggunakan empat metode yaitu metode pembiasaan, metode keteladanan, metode penyadaran (nasehat), dan metode pengawasan atau pengontrolan. ${ }^{40}$

Metode pertama, pembiasaan disini yaitu Shalat dhuha berjamaah yang dilaksanakan secara bergilir dari kelas satu sampai kelas tiga. Sedangkan kelas empat sampai kelas enam melaksanakan shalat dzuhur berjamaah. Fasilitas yang kurang memadai dan keadaan masjid yang tidak mampu menampung seluruh siswa dalam waktu yang sama, sehingga mengharuskan adanya penjadwalan shalat dhuha berjamaah dan shalat dzuhur berjamaah. Pelaksanaan shalat dhuha berjamaah dimulai pada pukul 08.30 WIB sampai dengan pukul 09.00 WIB. Berdasarkan observasi yang peneliti lakukan bahwa sebelum memulai shalat dhuha, anak-anak dibiasakan untuk membaca do'a sebelum masuk masjid, setelah itu melaksanakan ibadah shalat dhuha berjamaah, dilanjutkan membaca do'a shalat dhuha dan diakhiri membaca doa keluar masjid secara bersamasama. ${ }^{41}$

Metode kedua, keteladanaan yaitu semua guru wajib memberikan contoh atau tauladan yang baik kepada siswa didiknya. kerena keteladanan dalam dunia pendidikan merupakan metode yang paling berpengaruh bagi anak-anak. Ketika anak berusia 7 sampai 8 tahun mereka mengalami masa mencontoh (imitasi), apa yang dilihat, didengar akan ditiru. Guru merupakan sebagai pendidik sekaligus contoh bagi anak-anak didiknya.

\footnotetext{
${ }^{40}$ Hasil wawancara dengan guru bimbingan konseling,tanggal16 agustus 2016

${ }^{41}$ Hasil observasi, tanggal 08 agustus 2016
} 
ketika para pendidik memberikan contoh yang baik. Maka anak-anak akan berbuat seperti yang mereka lihat dan mencontoh. Metode ini memberikan salah satu contoh dalam membentuk karakter anak yang hendaknya dilaksanakan dalam kehidupan sehari-hari seperti shalat dhuha berjamaah. ${ }^{42}$

Metode ketiga, dengan metode penyadaran (nasehat), maksud penyadaran disini yaitu memberikan penjelasan-penjelasan tentang pentingnya peraturan-peraturan yang telah diadakan sehingga lamban laun anak itu akan sadar terhadap peraturan-peraturan khususnya peraturan shalat dhuha berjamaah, selain menyadarkan peraturan guru kelas juga memberikan materi agama kepada anak melalui pelajaran fiqh. Yaitu untuk mengetahui bagaimana tata cara shalat, rukun dan wajib shalat, manfaat shalat dll. Sehingga anak termotivasi untuk mau melaksanakan ibadah shalat berjamaah melalui metode penyadaran dan memberikan motivasi kepada anak didiknya. ${ }^{43}$

Sedangkan metode yang terakhir yaitu menggunakan metode pengawasan atau pengontrolan kepada anak hiperaktif ketika shalat dhuha berjamaah berlangsung. Tujuan dari pengawasan atau pengontrolan ini yaitu untuk menjaga atau mencegah agar tidak terjadi sesuatu yang tidak diingginkan khususnya yang bertentangan dengan peraturan yang telah diadakan di sekolah. Sehingga dengan pengawasan tingkat kedisplinan anak akan terkontrol dengan baik. setelah pengawasan atau pengontrolan yang dilakukan oleh wali kelas dan guru bimbingan konseling bisa berjalan dengan baik, tinggal menerapkan peratutran yang telah dibuat yaitu ketika berlangsungnya ibadah shalat dhuha anak yang tidak bisa diam, masih gojek, tidak bisa tenang, mengganggu teman atau membuat keributan maka anak akan mendapatkan hukuman yaitu dengan mengulangi shalat dhuha sendiri untuk kedua kalinya. Hukuman disini bertujuan untuk mendidik, melatih, mengendalikan dan memperbaiki tingkah laku anak. ${ }^{44}$

Dalam menanamkan metode kedisiplinan shalat dhuha pada anak hiperaktif merupakan kewajiban semua guru untuk mengajarkan nilai-nilai agama pada anak hiperaktif. Baik saat pelajaran berlangsung maupun di saat melaksanakan ibadah shalat dhuha berjamaah. Pemberian bimbingan dan konseling Islam, bertujuan untuk mencari jati diri dalam bentuk perubahan diri, sikap, tingkah laku dan mengembangkan kemampuan potensi yang dimiliki untuk bertahan hidup di lingkungan, sekolah maupun masyarakat.

\footnotetext{
42 Hasil observasi,tanggal 08 agustus 2016

43 Hasil observasi,tanggal 08 agustus 2016

${ }^{44}$ Hasil observasi,tanggal 08 agustus 2016
} 
Menanamkan kedisiplinan sholat dhuha berjamaah merupakan suatu proses latihan dan pembiasaan. Jadi menanamkan kedisiplinan pada anak hiperaktif disini yaitu sebagai upaya melatih konsentrasi sekaligus memberikan bimbingan agama kepada anak hiperaktif, sehingga akhirnya mereka memiliki suatu disiplin dalam dirinya dalam melaksanakan ibadah. Seperti kita ketahui indikator didalam kedisiplinan dalam beribadah yaitu datang tepat waktu ketika melaksanakan ibadah shalat, mematuhi peraturan yang sudah dibuat dalam melaksanakan ibadah shalat dan mengikuti kegiatan sesuai jadwal, agar dapat disiplin di butuhkan pembagian jadwal sehingga anak hiperaktif di latih untuk bisa mengikuti sesuai jadwal yang sudah ditentukan. ${ }^{45}$

\section{Simpulan dan Rekomendasi}

Karakteristik anak hiperaktif merupakan suatu pola perilaku pada seseorang yang menunjukkan sikap tidak mau diam, tidak menaruh perhatian dan impulsif. Selain itu anak yang hiperaktif selalu bergerak, tidak mau diam bukan dalam situasi-situasi yang menuntut agar mereka selalu tenang. Dengan kata lain anak hiperaktif mengandung arti yang lebih mendalam dari sekedar sebagai tingkah laku yang sangat aktif. Terdapat tiga anak yang termasuk kriteria anak hiperaktif di MI Nurul Islam Ngaliyan Semarang.

Pertama, anak yang berinisial " $\mathrm{H}$ " memiliki karakteristik sangat aktif, suka jalan kesana-kesini, susah berkonsentrasi. Kedua, anak berinisial "A" memiliki karakteristik tidak bisa diam, selalu mengganggu teman, tidak sabar menunggu giliran, susah untuk memfokuskan. Ketiga, anak berinisial "Y" memiliki karakteristik sulit dikendalikan, tidak bisa diam, suka menentang, dan semaunya sendirinya. Dari ketiga anak tersebut memiliki ciri-ciri yang menunjukkan bahwa anak tersebut termasuk anak hiperaktif.

Metode bimbingan dan konseling Islam dalam menanamkan kedisiplinan shalat dhuha pada anak hiperaktif di MI Nurul Islam Ngaliyan Semarang. Menggunakan empat metode yaitupertama, dengan metode pembiasaan, pada langkah ini sekolah memberikan jadwal kelas mulai dari kelas satu sampai tiga sehingga anak diajak untuk membiasakan shalat dhuha berjamaah. Kedua, dengan metode tauladan atau contoh, yaitu guru memberikan contoh kepada siswa melaksanakan shalat berjamaah. Ketiga, dengan metode penyadaran dan memberikan nasehat, adapun bentuk penyadaran atau memberikan nasehat kepada siswa yaitu saat

${ }^{45}$ Hasil observasi,tanggal 08 agustus 2016 
penyampaian materi yang diberikan pelajaran fiqh dan ceramah. Keempat, dengan metode pengawasan, pengawasan yang dilakukan oleh wali kelas dan guru pembimbing, guna mengontrol keterlibatan dalam shalat dhuha berjamaah. Dari hasil penelitian menunjukkan bahwa kerjasama yang terjalin antara kedua belah pihak sudah berjalan dengan baik dalam menanamkan kedisiplinan shalat dhuha pada anak hiperaktif menggunakan empat metode yang terapkan di MI Nurul Islam Ngaliyan Semarang.

\section{DAFTAR PUSTAKA}

Arifin, Pokok-Pokok Pikiran Tentang Bimbingan dan Penyuluhan Agama, Jakarta: Bulan Bintang, 1976

Deiphie,Bandi,Layanan Perilaku Hiperaktif, Klaten: PT. Insani, 2009

Departemen Agama RI, Al-Qur'an dan Terjemah , Jakarta: Al-Jumanatul, 2004

Departemen Pendidikan Nasional, RI, Kamus Besar Bahasa Indonesia,(Edisi Ketiga), Jakarta: Balai Pustaka, 2005

Hamdani, Bimbingan dan Penyuluhan, Bandung: Pustaka Setia, 2012

Hamida, Abu, Indahnya dan Nikmatnya Shalat: Jadikan Shalat Anda Bukan Sekedar Ruku dan Sujud, Bandung: Pustaka Hidayah, 2009

Hurlock, Perkembangan Anak Jilid I, Jakarta: Erlangga, 1989

Imam Abu Zakariya Yahya bin Syarif, An-Nawawi , Terjemahan Riyadhus Shalikin Jilid I, Bandung: Al-Ma'arif, 1987

Irawati, Ismail, Mengatasi Problem Anak Sehari-hari, Jakarta: PT Gramedia Pustaka Utama, 2009

Jamaludin, Syekh, Psikologi Perkembangan Anak dan Remaja Muslim, Jakarta: Pustaka Al-Kautsar,2003

Mansur, Pendidikan Anak usia dini dalam islam, Yogyakarta: Pustaka Belajar, 2014 
MuhaiminAzzeet, Akhad, Bimbingan Konseling di Sekolah, Yogyakarta: ArRuzz, 2011

Muhammad ibnu Ahmad Al-Ansori, Abdullah, Tafsir Al-Qurtubi, Jakarta: Manshuurah, 2001

MunirAmin, Samsul, Bimbingan dan Konseling Islam, Jakarta: AMZAH, 2010

Prayetno dan Erman Amti,Dasar-dasar Bimbingan dan Konseling, Jakarta: 2008

Quraish Shihab,Muhammad, Tafsir Al-Misbah: pesan, kesan, dan keserasian Al-Quran , Jakarta: Lentera Hati,2008

Rahim, Faqih,Aunur, Bimbingan dan Konseling dalam Islam, Yogjakarta: UI Press, 2001

Rifa'i, Mohamad, Risalah Tuntunan Shalat Lengkap, Semarang: PT. Thoha Putra, 2015

Rohmah, Elfi Yuliana, Psikologi perkembangan, Ponorogo: STAIN Ponorogo Press, 2005

Samsul Munir, Amin, Bimbingan dan Konseling Islam, Jakarta: AMZAH, 2010

Sutoyo,Anwar, Bimbingan dan Konseling Islam (Teori dan Praktik), Yogyakarta: Pastaka Belajar, 2013

Syekh Jamaludin, Mahfudz,, Psikologi Perkembangan Anak dan Remaja Muslim, Jakarta: Pustaka Al-Kautsar,2003

Taylor, Erik, Anak yang Hiperaktif, Jakarta: Gramedia, 1992

Tu'u, Tulus, Peran Disiplin pada Perilaku dan Prestasi Siswa, Jakarta: Grasindo, 2004

Wiramiharjo, Pengantar Psikologi Abnormal, Bandung: PT. Refika Aditama, 2008

Zeviera, Ferdinand, Anak Hiperaktif Cara Cerdas Menghadapi Anak Hiperaktif dan Gangguan Konsentrasi, Yogyakarta: Ar-Ruzza, 2007

Wawancara dengan guru bimbingan konseling, tanggal 08 aguatus 2016

Wawancara dengan wali kelas, tanggal 16 agustus 2016 